\title{
Analyzing Ethnocentric Immigration through the Case of Hungary - Demographic Effects of Immigration from Neighboring Countries to Hungary
}

\author{
Márton Péti ${ }^{1}$ \\ Research Institute for National Strategy, Corvinus University of Budapest, Hungarian \\ Laura Szabó and Csilla Obádovics \\ Hungarian Demographic Research Institute, Hungarian \\ Balázs Szabó and Dávid Csécsi \\ Research Institute for National Strategy, Hungarian
}

\begin{abstract}
Specific ethnocentric international migration processes can be observed in Hungary: a significant proportion of immigrants are of Hungarian ethnic background and come from neighboring countries. Similar processes can be observed between other kinstates and co-ethnic communities of Central and Eastern Europe, but this type of migration has not been studied intensively yet. The focus of the research is on the effects of this immigration on Hungarian society and the economy. Population projections were also carried out according to two research questions: "what would have happened if the immigrants had not arrived according to the processes that were experienced?" and "what will happen if the immigration process changes?" The research is based on the 2011 census data sets; the target group is the population born in neighboring countries that moved to Hungary after 1985. Results show that the ethnic Hungarian immigrant population has been a crucial human resource in Hungary. Without these immigrants, Hungary's demographic trends would also be less favorable. Moreover, in contrast to the situation typical of European immigrants, the socio-economic situation of the former is more favorable than of the host society. Potential decline of this immigration population could indeed be challenging.

Keywords: ethnocentric migration, migration, Hungary, Central and Eastern Europe, demography, population projection
\end{abstract}

The main characteristics of migration that affect Hungary do not differ significantly from international and Central and Eastern European processes. However, a deeper analysis shows that, in the last thirty years, the Hungarian situation has had specific features. These include the emergence of mass immigration since the late 1980s, which has only recently become a significant phenomenon in several states of the region. It is also a peculiar feature that a significant proportion of immigrants speak the same language and have the same ethnic background as the host population. This ethnocentric type of migration can also be observed in some other Central and Eastern European (CEE) countries, too. Unlike more general immigration policies, ethnocentric migration is even encouraged by certain national policies in

\footnotetext{
${ }^{1}$ Corresponding Author E-Mail: marton.peti@uni-corvinus.hu
} 
CEE. Still, it has been researched to a lesser degree than other migration processes related to this macroregion. Examining Hungarian ethnocentric migration may provide lessons for future studies and contribute to the better understanding of this phenomenon in CEE or even globally.

The case of Hungary has both emblematic and distinct features, as ethnic Hungarians perhaps comprise the largest native minority population in CEE (or at least one of the largest depending on different regional delineations and different definitions of native minority communities). So, the population of Hungary probably relies significantly on immigration flows originating from these communities. It is a very sensitive interdependency, as the official Hungarian national strategic doctrine since the 1990s has concerned the need to sustain native ethnic Hungarian minority communities, rather than encouraging their immigration to Hungary (unlike, for instance, with Germans to Germany since the 1980s).

The geographical pattern of ethnocentric international migration in Hungary is similar to that of internal migration processes: from peripheral areas located mostly along the borders of the country towards central and western urban centers (Gödri, 2010). Communities of ethnic Hungarians as sources of Hungarian immigration are mainly located close to the Hungarian border in almost all locations around Hungary, and in other inner peripheral areas of neighboring states.

The research described here was designed to provide a comprehensive overview of the wave of Hungarian immigration that originated in neighboring countries (and their predecessor states), starting from the end of the 1980s and continuing to the present day. Since a decrease has been observed in this immigration flow recently, research questions have also addressed the possible long-term demographic challenges caused by this tendency. Other questions concern the effects of this kind of immigration on the demography, society, and economy of Hungary.

\section{Current Patterns of CEE Migration and Theories Behind Emigration from CEE}

A mass migration of Central and Eastern European labor force towards the European core areas is a dominant social feature. This process has already started from the mid-1990s. After the EU (European Union) accessions, the previously expected large wave of migration to the West did not start everywhere or all at once, but nonetheless tens of thousands of migrants left the region each year and the net migration rate in Central and Eastern European countries become robustly negative (DeWaard \& Raymer, 2012).

This migration inside the EU was mainly driven by differences in wages, and strengthens centre-periphery relations and the dependency of the CEE within the EU (e.g. Matzhanova \& Simtikov, 2021; Salamin, 2015a, 2015b; Simionescu, 2016; Török, 2017). The steady migration of the working-age population from CEE to Western Europe - along with the low birth rates and relatively unfavorable mortality rates in the region - lead to significant aging and depopulation (Frejka \& Gietel-Basten, 2016; Lutz, 2010). These demographic trends may significantly impact employment, public services, and the sustainability of the pension system. According to Rees et al. (2012), the workforce in Eastern Europe may decline by $30 \%$ in 2050.

As a high proportion of CEE immigrants are well educated, a brain drain occurs in CEE, or even a "brain waste" as highly educated CEE immigrants frequently end up in low skilled jobs (Kaczmarczyk 2010; Schneider, 2021). (CEE immigrants in the EU have realized a generally lower socio-economic status than the native population but better than non-European migrants [e.g. Zubíková, 2019]). However, positive effects of this emigration on the CEE economies, such as lowering unemployment or stimulating economic growth, can also be explored (Kaczmarczyk et al., 2020; Schneider, 2021). Still, significant long-term development perspectives and catching up of CEE economies with the Western European core areas probably 
cannot be realised with high levels of emigration (Grieveson, 2019; Piatkowsky, 2013; Smętkowski, 2018).

The abundant literature on recent emigration from CEE - which is especially rich in the context of Polish and Romanian population having the highest emigrant rates - examines not only long-term permanent emigration, but other frequently appearing forms, too, e.g.: a return to the home country or a circulation (e.g. Croitoru, 2021; Drinkwater \& Garapich, 2015; Strockmeijer et al., 2019), as well as multiple further migration (Ciobanu, 2015).

Due to the shortage of labor caused by emigration many CEE countries themselves have become target areas of labor force migration since the mid-2010s (Brunarska et al., 2016; Jaroszewicz, 2018). The main sources of this new immigration are regions lying east and south of the EU. EU Member States of CEE started to compete with each other and Western Europe for this labour in the 2010s (first of all for Ukrainian immigrants). As a consequence, CEE labour markets became more open and ethnocentric migration enhanced (see later) (Jaroszewicz, 2018). In the meanwhile, other policies on immigration have not changed much, since in CEE the political and public arguments on immigration (in line with the social attitudes towards [non-European] immigrants) are rather mistrustful compared to other parts of the EU (among others e.g. Matusz et al., 2020; Peshkopia et al., 2021; Prucova Hruzova, 2021).

\section{A Special Way of Mobility in CEE: Ethnocentric Migration}

Besides east-west migration patterns discussed above, another characteristic CEE migration process evolved between communities which have similar ethnic backgrounds. This type of migration is a traditional feature in this macroregion where ethnic minority communities exist in a high density (cf. e.g. the density of minority languages, which is much higher in CEE than in Western European countries [Council of Europe, 2015]). During the first stage of postsocialist migration, from the late 1980s onwards, relocation occurred mainly between CEE countries, and mostly on the basis of ethnicity: the national or ethnic minority population moved to countries where the same nationality or ethnicity makes up the majority (ethnic and national minorities are not differentiated in this study). Examples include German, Turkish, and Hungarian minority communities, as well as the ethnic communities of former Yugoslavia and the former Soviet Union. We define this type of migration as ethnocentric in this study, mentioning the related migrant community as ethnocentric migrants or immigrants. Ethnocentric migration provides a geographic frame or a network for migrants with various motivations (e.g. seeking for jobs, family reunion or even asylum).

Coleman (2009) set up a global prognosis on the growing demographic diversity of more developed macroregions and the remaining homogeneity of less developed ones. This concept can be supported in a European context through ethnocentric migration by taking into account the potential significance of ethnocentric migration in a peripheral macroregion (CEE), the migration patterns of the more developed Western European core areas, as well as the differences between the national migration strategies inside the EU.

Ethnocentric migration has probably remained a significant process in CEE, still it has not become a popular research subject compared to the emigration mentioned above. However, there are some studies that touch upon this subject. Ethnocentric migration may be stimulated in the region by the strong historical and cultural links between some of the CEE countries. This is true of the Czech Republic and Slovakia (e.g. Horáková, 2000), the countries of the former Yugoslavia (e.g. Raduaiki, 2016; Valenta et al., 2016), the countries of the former Soviet Union, especially in the case of the Russian population (Heleniak, 2001; Molodikova, 2007), and Poland and its eastern neighbours (Brunarska \& Lesińska, 2014). Geopolitical position may strongly influence ethnocentric migration behavior. For instance, minority communities out of 
Péti, M.

the EU can be outstandingly mobile towards their EU member kin-state, e.g. Poles in Belarus (Wallace \& Patsiurko, 2017) or Hungarians in Ukraine or Serbia (Péti et al., 2018).

Unlike immigration in general, ethnocentric migration is in many cases encouraged by the kin-states' policies in CEE. For instance, simplifications of policy requirements on visa and citizenship in the case of external co-ethnic communities have been introduced (e.g. Hungary, Poland, Romania-Moldova). These actions could not result in a more favorable demographic situation for the whole ethnic group (Dumbrava, 2018). They enabled emigration from the ethnic minority community towards destinations other than the EU member kin-state (e.g. Gödri, 2015; Tabac \& Gagauz, 2020), and also a short term and circular ethnocentric migration of labour (Brunarska et al., 2016).

Due to the scarcity in direct comprehensive research on CEE ethnocentric migration, our knowledge on its patterns and demographic, economic, social, cultural impacts is limited. This study aims to contribute to mapping this subject by exploring the Hungarian case, which is probably the most substantial in CEE.

\section{Hungary as a Field for Studying Ethnocentric Migration}

The situation of ethnic Hungarians may be one of the most emblematic markers of ethnocentric migration, as this population makes up large and specific communities. For example, in 2011 more than two million ethnic Hungarians were living in seven neighboring countries of Hungary, with communities numbering well in excess of 100,000 in four countries (Kapitány, 2013). Ethnic Hungarians have a highly distinctive (polarized) identity and language that distinguishes them from the majority populations (Kiss, 2014). This is because the territorial readjustments of Hungary after the First and the Second World Wars, native Hungarian minority communities were left isolated from their homeland.

Until the second half of the nineteenth century, Hungary was largely a beneficiary of international migration, but from then onwards until the fall of the communist regime in 1989 the yearly migration balance was mostly negative, and nearly 1,300,000 people left the country. This was only offset by Hungarians moving back to Hungary from regions detached from Hungary after World War I. From the 1990s onwards, the trends changed, as Hungary became a destination country (Kincses, 2015). On the one hand, the opportunity to return opened up for Hungarians who had previously emigrated or remained outside the border. On the other hand, migration processes within the region strengthened, and Hungary, which was in relatively good economic situation, became one of the target countries (Wallace, 2002). An ethnocentric pattern also labels this process motivated by better cultural or economic opportunity or (self-)exile.

Later on, the typical CEE emigration to Western Europe also appeared in Hungary. Even though the mass emigration observed among other countries that joined the EU in 2004 initially affected Hungary to a lesser extent, almost 400,000 people had left the country by 2010 . Moreover, in the first part of the 2010s, the annual number of emigrants rose to around 100,000 (Blaskó \& Gödri, 2014).

Migration and the socio-economic aspects of Hungary's immigrant population have been the subject of a large set of Hungarian studies (most recently e.g. Cseh Papp, et al., 2018; Kincses \& Tóth, 2019). Still, the ethnocentric immigrant population of the latest decades and its potential and quantifiable - supposedly great - impacts have not been studied specifically. 


\section{Research Methodology}

\section{Defining the Ethnocentric Immigrant Population in the Case of Hungary}

The research is based on the 2011 census data, and the target group is the population born in neighboring countries and their predecessor states (see Table 1) who moved to Hungary after 1985.

The research basically focuses on the most recent ethnocentric migration the movement of Hungarians ${ }^{2}$ based on individual decisions, as well as due to very high-impact mass migration, which is why we have applied a time constraint to largely filter out internal migration that occurred before the border changes and forced demographic movements associated with international treaties. Due to our data, migration had started to increase gradually already after 1985 which reflects the historical background of cause of migration: in Romania hosting the most populous ethnic Hungarian community a political persecution of ethnic Hungarians started in 1984 as well as the living standards dropped (Bottoni, 2017).

In addition to the limits posed by the timeframe, we applied a territorial limitation as the aim was primarily to study the migration characteristics of Hungarians living in countries neighboring Hungary and their predecessors (Table 1).

\section{Table 1}

Neighboring Countries and Their Predecessors Included in the Study

\begin{tabular}{ll} 
Country & \multicolumn{1}{c}{ Predecessor state } \\
\hline Slovakia & Czech Republic (Czechoslovakia) \\
& Russia, Kazakhstan, Estonia, Latvia, Lithuania, Moldova, \\
& Belarus, Armenia, Georgia, Azerbaijan, Uzbekistan, \\
& Turkmenistan, Tajikistan, Kyrgyzstan (Soviet Union) \\
Romania & Moldova \\
Serbia & Bosnia and Herzegovina, Macedonia, Montenegro, Kosovo \\
Croatia & (Yugoslavia) \\
Slovenia & \\
Austria & Germany \\
\hline
\end{tabular}

The definition of the immigrant population is based on the 2011 census methodology. On 1 October 2011 (at the time of the census), 83\% of the population born abroad $(318,897$ people) had been born in neighboring countries or their predecessors (Table 2). However, in the case of $22 \%$ of the examined population, the year of moving to Hungary is unknown: $11 \%$ of the latter $(33,814$ people) did not answer this question in the census, and 35,550 people answered that they had not lived abroad for at least one year, even though they were born abroad ( $11 \%$ of the examined population). In the former case, these individuals were presumably born and/or moved during/after the reorganization of the borders, so for them being born abroad did not mean living abroad.

\footnotetext{
${ }^{2}$ In the present study, the population described as "Hungarian" always refers to those who declare themselves to be of Hungarian ethnic background (in the census).

${ }^{3}$ Germany formed a joint state with Austria briefly (1938-45), but the reasons for involving Germany are as follows: it is easily accessible from Austria sharing the same language; it is a traditional destination for emigration from Hungary; there are a large number of immigrants arriving in Hungary from Germany.
} 


\section{Table 2}

Distribution of Immigrants Born in Neighboring Countries and Their Predecessors According to Country of Birth and Year of Immigration

\begin{tabular}{|c|c|c|c|c|c|c|}
\hline \multirow{3}{*}{$\begin{array}{l}\text { Place of } \\
\text { birth }\end{array}$} & \multicolumn{5}{|c|}{ Population born in the countries under analysis } & \multirow{3}{*}{$\begin{array}{l}\text { Year of } \\
\text { moving: } \\
\text { After } 1985 \\
\text { figures are } \\
\text { estimates }\end{array}$} \\
\hline & \multirow[t]{2}{*}{ Total } & \multicolumn{4}{|c|}{ Year of moving to Hungary } & \\
\hline & & $\begin{array}{c}\text { Before } \\
1985\end{array}$ & $\begin{array}{l}\text { After } \\
1985\end{array}$ & $\begin{array}{l}\text { Did not live } \\
\text { abroad }\end{array}$ & $\begin{array}{c}\text { Do not } \\
\text { know/ } \\
\text { No answer }\end{array}$ & \\
\hline Romania & 176,550 & 17,595 & 131,248 & 15,435 & 12,272 & 155,955 \\
\hline Ukraine & 35,354 & 5,727 & 20,985 & 3,086 & 5,556 & 28,587 \\
\hline Slovakia & 33,155 & 14,290 & 9,321 & 8,486 & 1,058 & 10,641 \\
\hline Serbia & 29,144 & 4,193 & 16,926 & 3,166 & 4,859 & 22,125 \\
\hline Germany & 22,605 & 3,305 & 10,709 & 2,023 & 6,568 & 18,060 \\
\hline Russia & 6,690 & 2,043 & 3,373 & 703 & 571 & 4,225 \\
\hline Austria & 6,160 & 677 & 2,630 & 1,213 & 1,640 & 4,695 \\
\hline Croatia & 3,498 & 1,401 & 1,140 & 746 & 211 & 1,410 \\
\hline $\begin{array}{l}\text { Czech } \\
\text { Republic }\end{array}$ & 1,337 & 479 & 431 & 282 & 145 & 555 \\
\hline $\begin{array}{l}\text { Other } \\
\text { Soviet } \\
\text { successor } \\
\text { states }\end{array}$ & 1,288 & 163 & 733 & 116 & 276 & 1,072 \\
\hline $\begin{array}{l}\text { Other } \\
\text { Yugoslav } \\
\text { successor } \\
\text { states }\end{array}$ & 748 & 24 & 552 & 32 & 140 & 703 \\
\hline Slovenia & 657 & 165 & 182 & 174 & 136 & 344 \\
\hline $\begin{array}{l}\text { Bosnia } \\
\text { and } \\
\text { Herzegovi } \\
\text { na }\end{array}$ & 506 & 68 & 323 & 29 & 86 & 415 \\
\hline $\begin{array}{l}\text { Kazakhsta } \\
\mathrm{n}\end{array}$ & 482 & 60 & 296 & 27 & 99 & 402 \\
\hline Moldova & 267 & 11 & 158 & 14 & 84 & 234 \\
\hline Latvia & 161 & 34 & 71 & 8 & 48 & 105 \\
\hline Lithuania & 161 & 32 & 96 & 6 & 27 & 117 \\
\hline Estonia & 134 & 19 & 73 & 4 & 38 & 108 \\
\hline Total & 318,897 & 50,286 & 199,247 & 35,550 & 33,814 & 249,753 \\
\hline
\end{tabular}

Note. Source: Hungarian population census data 2011. Copyright 2021 by HCSO \& RINS.

Taking into account only the number of immigrants by year of immigration, the population moving to Hungary is 199,247 (Table 2). However, using this criterion 70,000 people would be excluded from the analysis (as 70,000 people did not answer this question during the 2011 census). To avoid this, the year of moving was estimated with the help of known dates of immigration based on country of birth and year of birth. We replaced the missing values with the median year of migration of persons born in the same country and in the same year (assuming that the median year of immigration for immigrants from country $X$ and birth cohort $Y$ is not different for those of non-respondents from the country $X$ and birth cohort $Y$ ). Thus, $99.7 \%$ of the missing values were replaced. If no year of migration and/or year of birth were given for a country, due to the lack of data those individuals were excluded from 
the analyses, but this situation applied to only 148 cases. In line with the above-described method, a total of 249,753 individuals were successfully included in the analysis (Table 2).

\section{The Methodological Background of Population Projections}

The research also covers the effects of the ethnocentric immigrant population on the demographic trends of Hungary. In relation to the past, the research question was: "what would have happened if the ethnocentric immigrants had not arrived?" In this case, from 1990 onwards, we projected the population figures by leaving out those arriving from neighboring states.

Another research question was focused on the future: "what will happen if the ethnocentric immigration process changes?" The research related to these issues (population projections) only dealt with immigration from the four large ethnic Hungarian communities in Romania, Slovakia, Ukraine, and Serbia. These were based on the baseline version of the population projection made by the Hungarian Demographic Research Institute (HDRI) in 2015 (hereinafter referred to as the 'official population projection') (Földházi, 2015), which was modified on the basis of three hypotheses. The input data were the annual population statistics on the number of immigrants, year of birth, sex, and citizenship, as well as the population records.

The population projection was undertaken using the cohort component method, the components of which, in addition to population, are births, deaths, and migration balances. According to the official population projection, which is also used in the present research, the total fertility rate will reach 1.6 by 2021 and last until 2060, with a life expectancy at birth of 89 years for women, 85 years for men, and a migration balance of a surplus of 7,500 people (Földházi, 2015).

For the population projection, the annual demographic data, annual migration data, immigration data from four neighboring countries between 1985 and 2015 and population projection data (births, deaths, migration and population) were already known from the official population projection. In addition, annual data on migration from neighboring countries included in the study were calculated, by age and sex based.

The proportion of immigrants from the four neighboring countries within the total number of immigrants, which was already considered in the official population projection, had to be revised. The official population projection did not differentiate immigration by country of origin. According to citizenship, between 1990 and 2004 the proportion of immigrants from these four countries among the total number of immigrants was around $80 \%$, which then fell sharply to less than $50 \%$ in 2010 . One of the reasons for this was the economic crisis, and the other the simplified process of obtaining Hungarian citizenship that was introduced in 2010 (because of which some immigrants arrived in Hungary as Hungarian citizens) (Dumbrava, 2018; Gödri, 2015). According to another piece of research, if immigrants with Hungarian citizenship are taken into account, we see an increase rather than a decrease during the period 2011-2013 (Gödri, 2015). Although this calculation is limited to the years between 2011 and 2013 , it proves to be sufficient for an estimate of future trends. With this correction, the proportion of Hungarian immigrants was still around 50\% even in 2013 (without the correction it would have been around 40\%). We applied an exponential approach to determine the expected migration numbers in the population projections. Results indicate that in the official population projection the proportion of immigrants from the four neighboring countries will be $41.4 \%$ in 2040 and $38.8 \%$ in 2060 . The number of immigrants from 2023 will exceed the average of the last 30 years.

These were the results that we modified in line with the three different hypotheses: two of them calculated along reduced levels of immigration according to different geopolitical 
situations; the third one calculated an increase in short term followed by a long-term decrease caused by the expiring demographic resources of ethnic Hungarian communities (see details later).

\section{Results: Demographic and Human Resources of Ethnocentric Immigrants}

\section{Main Demographic Characteristics}

This population of about 250,000 that have immigrated since the mid-1980s accounts for about $78 \%$ of all immigrants from neighboring countries and their predecessor states (Figure 1). (We mention this population in this chapter as 'ethnocentric immigrants' or simply just immigrants.) Among the larger and predominantly Hungarian immigrant groups, only from the former Czechoslovakia did fewer people move to Hungary after 1985 than before. This region was affected by serious political crisis involving Hungarians only before 1985, unlike the other neighboring regions that have also suffered from economic collapse and even armed conflict since the mid-1980s.

\section{Figure 1}

Distribution of Immigrants Born in Neighboring Countries and Their Predecessors by Year of Immigration and Country of Birth, \%

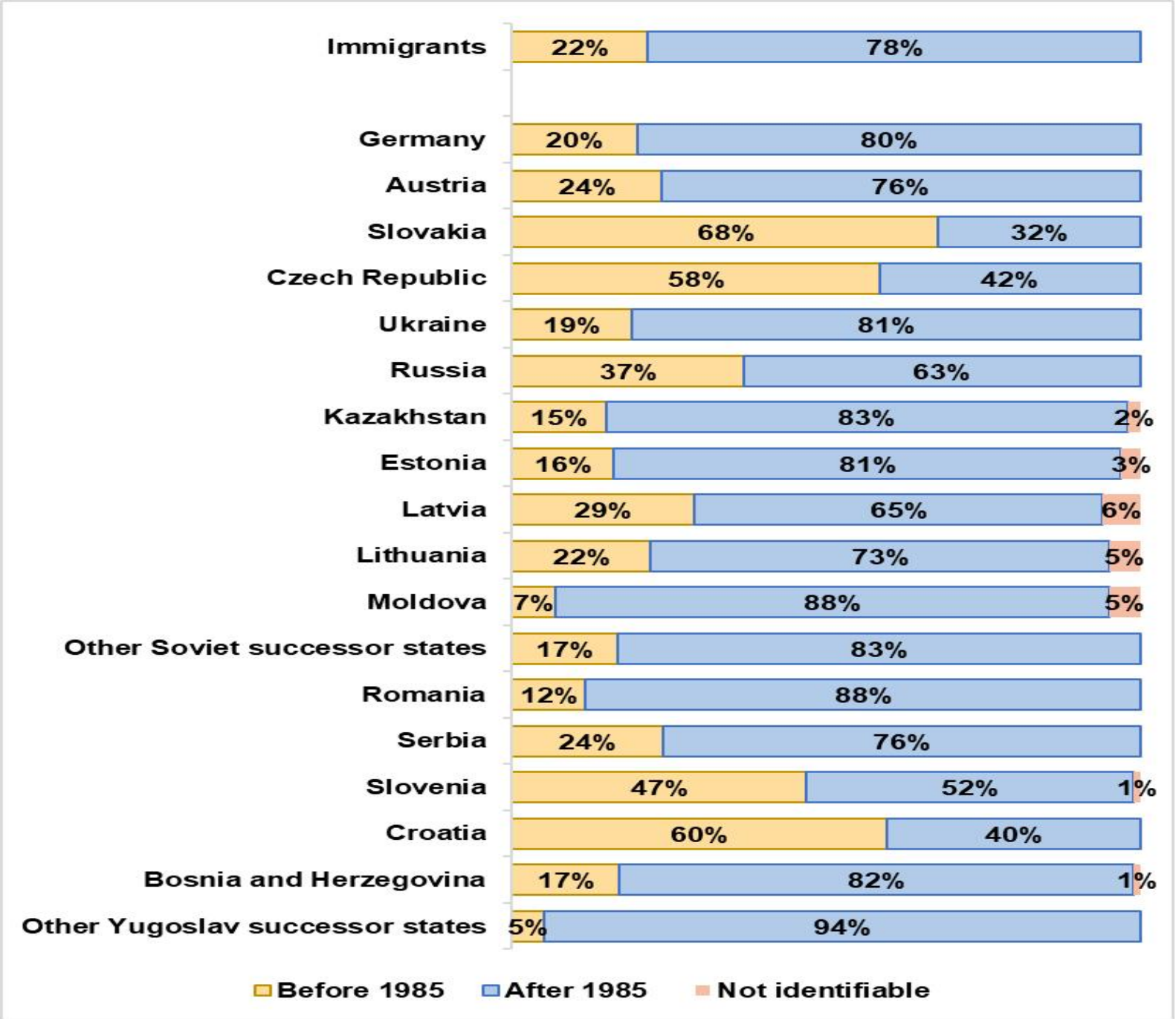

Note. Source: Hungarian population census data 2011. Copyright 2021 by HCSO \& RINS. 
There is no significant difference in terms of gender between ethnocentric immigrants and the total Hungarian population (Figure 2). Among the larger immigrant groups, those with Serbian origins are the exception, with a high proportion of men who were fugitives from the forced conscription associated with the Yugoslavian Wars. Members of another relatively large immigrant community from Germany and Austria consist mainly of non-native Hungarians and include resettling German Hungarians, and former Hungarian emigrants who frequently have business motivations (i.e. the acquisition and operation of businesses) (Péti, 2017). Therefore, the overrepresentation of men among them is in line with European trends (Strey et al., 2018).

\section{Figure 2}

Distribution of Immigrants Born in Neighboring Countries and Their Predecessors by Gender and Country of Birth, \%

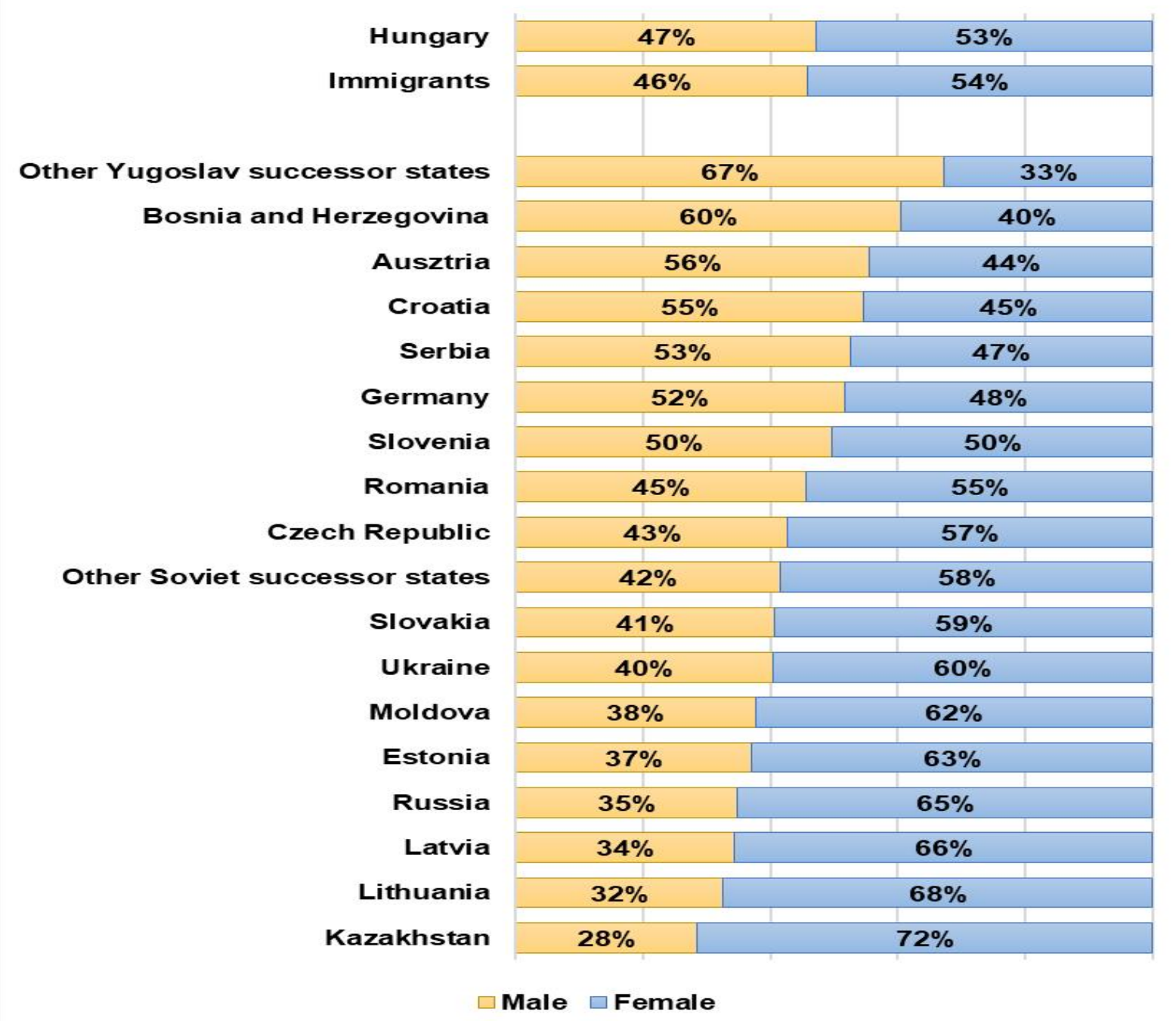

Note. Source: Hungarian population census data 2011. Copyright 2021 by HCSO \& RINS.

There are significant differences between ethnocentric immigrants and the population of Hungary concerning age. Among the immigrant population, the proportion of the active age group (15-64 years) is much larger than in the Hungarian population.

It is also clear that there is a relatively small difference in the proportion of the elderly (over 65), so the higher proportion of the active age group is to the 'detriment' of the young age group of 0-15 (Figure 3). The most aged population is from Austria: German and Austrian pensioners often settle down in Hungarian recreational areas (e.g. Péti, 2017). 


\section{Figure 3}

Immigrant Population Broken Down by Proportions of Young, Active, and Elderly, \%

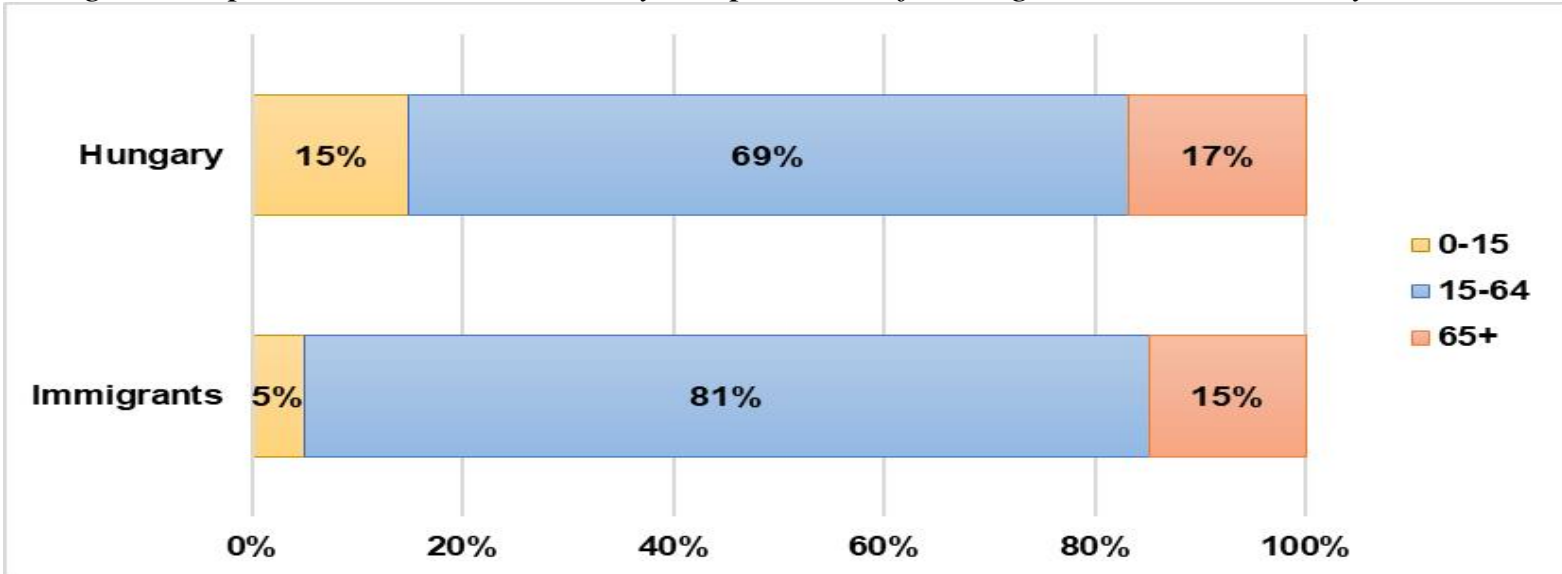

Note. Source: Hungarian population census data 2011. Copyright 2021 by HCSO \& RINS.

Examining the population in more detail using age groups of five years, the largest difference can be seen among those aged 40-44, who are represented in proportions of $7 \%$ in Hungary and almost 13\% among ethnocentric immigrants. (Figure 4).

In other words, the ethnocentric immigrants have not substantially rejuvenated the population of Hungary (because the proportion of young people among them is very small), but from the point of view of the national economy, the high proportion of people of working age represents an extremely important resource.

\section{Figure 4}

Distribution of the Immigrant Population by Age Groups of Five Years, \%

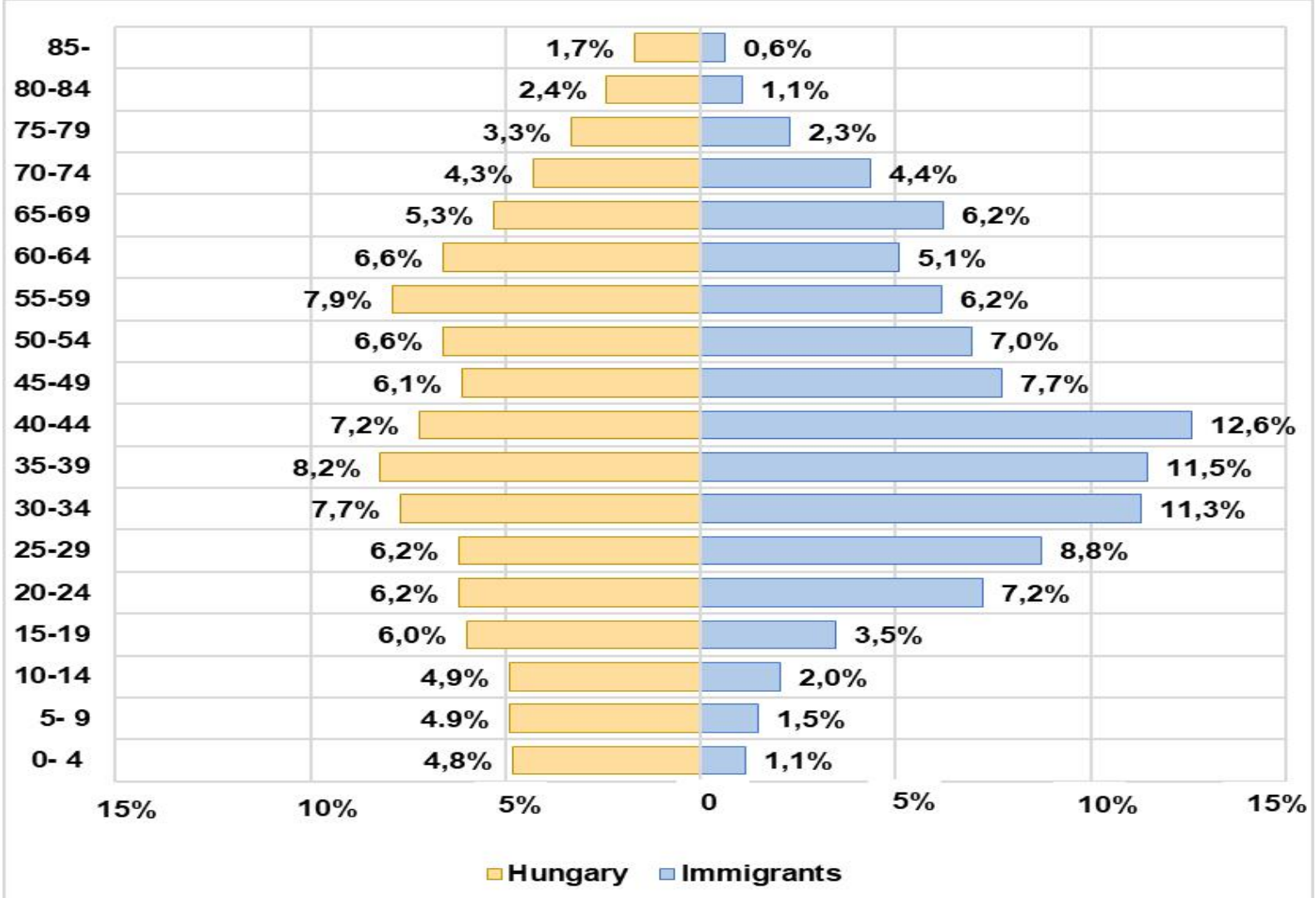

Note. Source: Hungarian population census data 2011. Copyright 2021 by HCSO \& RINS. 
The fertility of ethnocentric immigrant women is lower than the Hungarian average. While in Hungary there were 147 live births per 100 women aged 15 and older in 2011, the figure was only 130 per 100 immigrant women of the same age. This is presumably related to overall international migration patterns, according to which women involved in migration and the migrant population are more often forced to postpone or to give up on childbearing (Gödri, 2010). (This can be contrasted with the situation of women who have emigrated from Hungary to Great Britain, for whom higher fertility rate can be observed than of women in Great Britain or Hungary [Kapitány \& Spéder, 2015]).

Ethnocentric immigrants also contributed to the population of Hungary with their numbers. In 2011, their population of about 250,000 people made up $2.5 \%$ of the population of Hungary - a proportion much greater than, for example, the population of the largest native ethnic minorities in Hungary (German/Swabian, 1.9\% in 2011). Including also children born in Hungary to women aged 15+ who moved after 1985, the estimated number of immigrants and their children is 315,000 . This immigration can thus have a great impact on the population of Hungary and - concerning its age structure - an even greater one on the labor force (see below).

\section{Mother Tongue and Ethnic Background}

Among the ethnocentric immigrant population, 69\% declared themselves to be of Hungarian nationality or - in other words - to belong to the Hungarian ethnic community ( $84 \%$ in the case of total Hungarian population). ${ }^{4}$ In 13 of the 18 countries (or groups of countries) examined, it is primarily people with Hungarian nationality that moved to Hungary, while the second most common nationality is the majority nationality of the given country. Only in the case of five countries (Germany, Russia and the three Baltic States) is the majority nationality dominant among the immigrants; and here Hungarian is ranked in second place. The vast majority of the most populous communities from neighboring countries are Hungarians: 80\% of those arriving from Romania (accounting for nearly half of all ethnocentric immigrants) declared themselves to be of Hungarian nationality (and only 3\% other than Hungarian); from those arriving from Slovakia, Ukraine, and Serbia 66\% were of Hungarian nationality (and only $15 \%, 6 \%$, and 5\%, respectively, were other than Hungarian).

Sixty-eight percent of the studied population stated that their mother tongue was Hungarian. As we move further away from Hungary, the number of people of Hungarian nationality significantly decreases, but the proportion of Hungarian speakers decreases less. Although it is not known how many of those who declared themselves to be Hungarian in 2011 underwent a change of national/ethnic identity, it may be assumed that some of those who moved to Hungary from more distant countries may be affected by diaspora-specific patterns of identity (Bába, 2015) that do not link national identity to mother tongue.

Knowledge of the Hungarian language (Figure 5) is rather common; and it also plays a role in the Hungarian labor market, as it is still a basic requirement in almost all positions today (see other human resource-based characteristics in the next section).

\footnotetext{
${ }^{4}$ These figures are significantly influenced by non-respondents. The proportion of those whose nationality is other than Hungarian is only $2.2 \%$ in Hungary, and $7.4 \%$ among immigrants. The same situation applies to mother tongue (see later).
} 


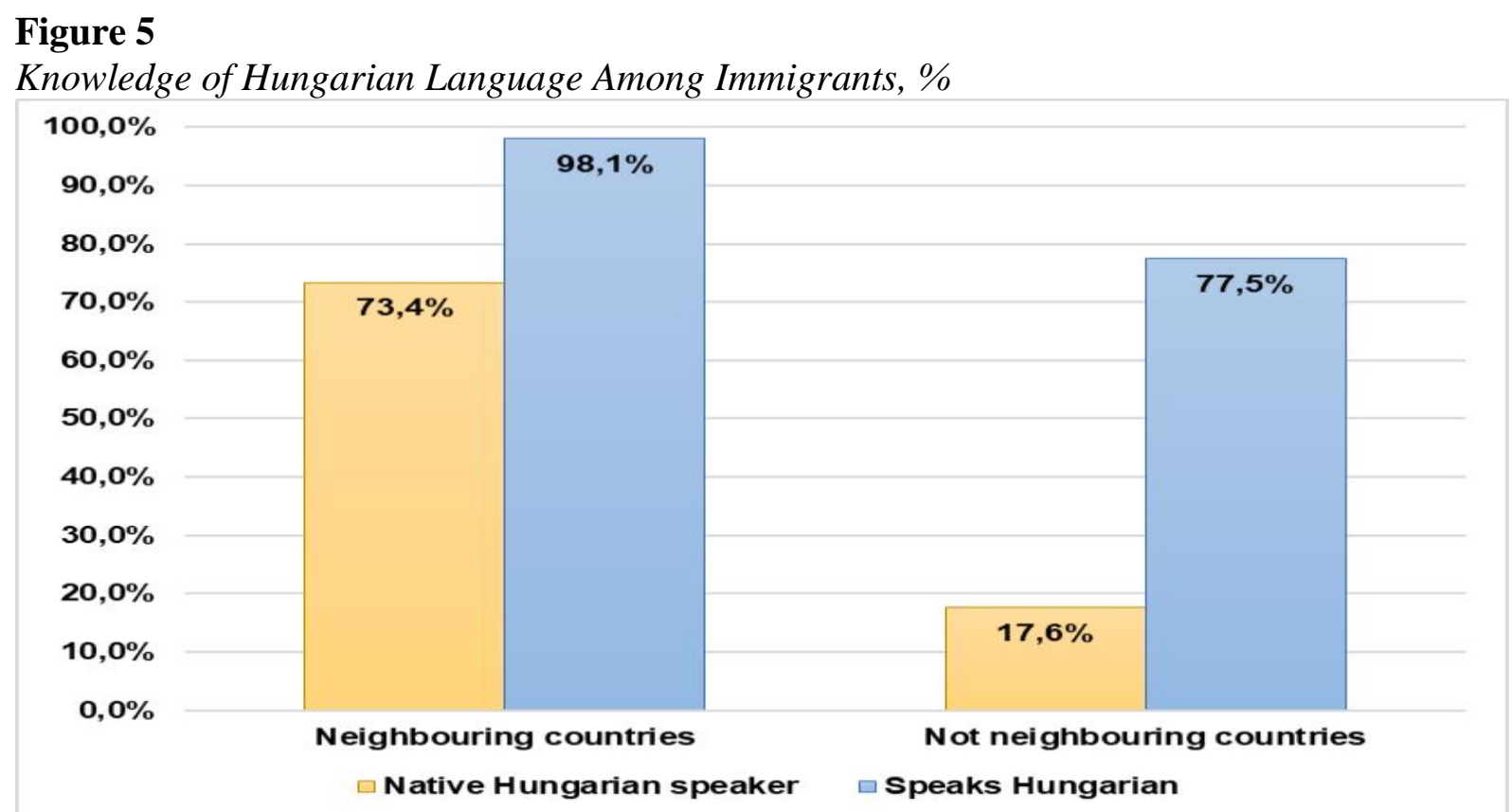

Note. Source: Hungarian population census data 2011. Copyright 2021 by HCSO \& RINS.

\section{The Added Value of Ethnocentric Immigrants in Terms of Human Resources}

Educational attainment fundamentally determines the chances of immigrants in the labour market. In line with previous research on overall immigrant population of Hungary (e.g. Kincses, 2015), the present research has found that ethnocentric immigrants to Hungary also have, on average, a higher level of education than the Hungarian population (Figure 6). The proportion of ethnocentric immigrants with a tertiary education from large Hungarian communities in the neighboring countries is significantly higher than the 2011 average for Hungary and the countries of origin, and notably higher than the 2011 figure for members of the Hungarian communities living in the countries of origin. ${ }^{5}$ This clearly refers to the significant drain of the skilled labor force. However, educational positions change rapidly in CEE: compared to more recent higher education data, 2011 data on immigrants appears to be favorable, but indicates less of an educational advantage. ${ }^{6}$

Knowledge of a foreign language is an important labor market advantage and may be a factor in making a decision to migrate; it also infers a higher-level education, so deductions can be made regarding this factor concerning both the probability of integration and economic opportunities. Ethnocentric immigrants generally speak the majority language of a neighboring country, unlike members of Hungary's population, which may be an advantage for some jobs, as well as enables immigrants to manage relationships between countries. The knowledge of the language of some neighboring countries (i.e. Romanian, Slovakian, etc.) is present in Hungary principally because of this immigrant population. $84 \%$ percent of all Romanian speakers in Hungary are from this immigrant population, as are $83 \%$ of Ukrainian-speaking people, but the proportion also exceeds $20 \%$ for all other languages.

\footnotetext{
${ }^{5}$ The proportion of people with a tertiary education in 2011: Slovakia: 20\%, Serbia: 17\%, Romania: 14\% (Ukraine: 12\% in 2001); Hungarians of Slovakia: 13\%, Hungarians of Serbia: 10\%, Hungarians of Romania: 10\%, Hungarians of Ukraine: 5\% (2001) (data source: national statistical offices, census data sorted by ethnic variable). ${ }^{6}$ Proportion of people with a tertiary education in 2018: Hungary: 23\%, Slovakia: 23\%, Serbia: 22\%,; Romania: 15\% (Ukraine: no data); Hungarians of Slovakia: 15\%, Hungarians of Serbia: 13\%, Hungarians of Romania: 16\%, Hungarians of Ukraine: 13\% (Péti et al., 2021).
} 
The ethnocentric immigrant community is also more advanced in terms of the knowledge of global languages (Figure 7), which may be primarily related to the higher education level (and perhaps also to more effective education outside Hungary).

\section{Figure 6}

Distribution of Population Aged 25 and Over by Education, \%

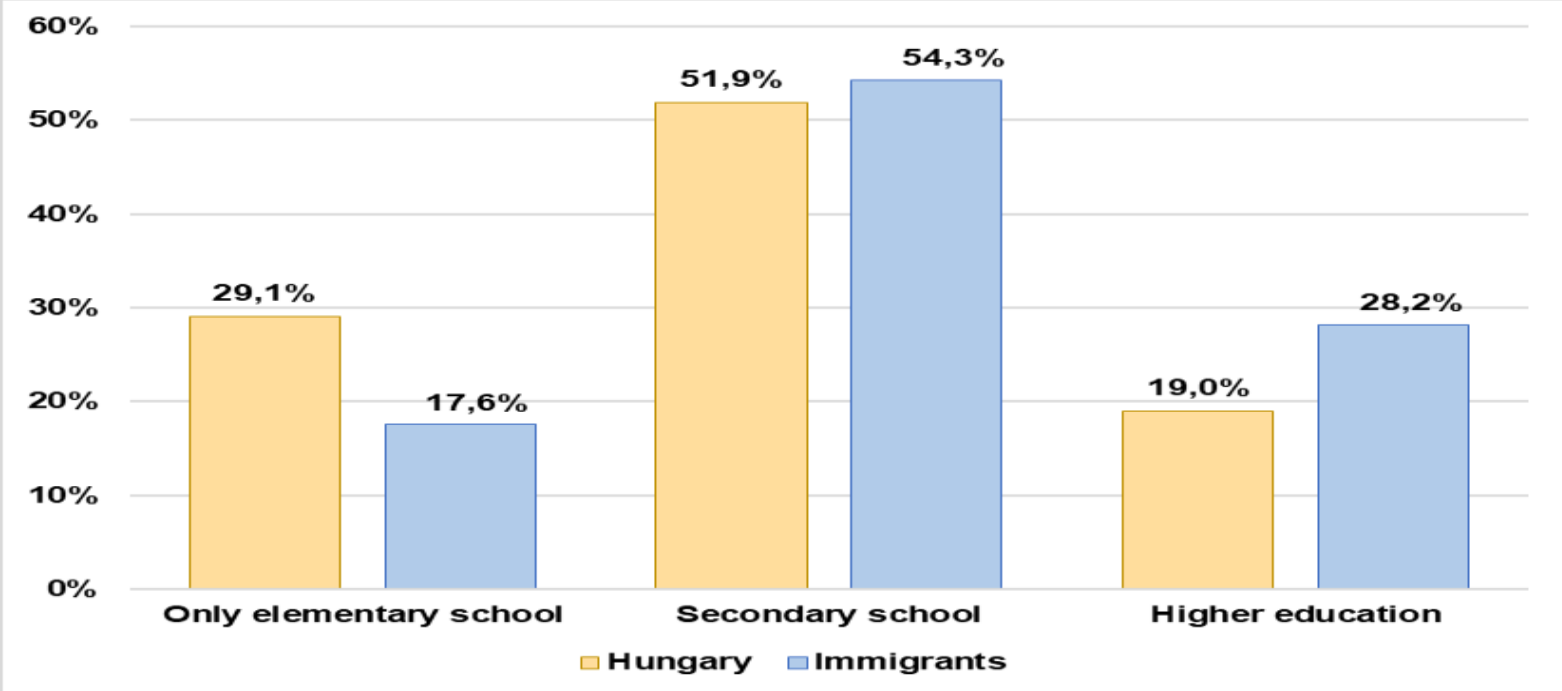

Note. Source: Hungarian population census data 2011. Copyright 2021 by HCSO \& RINS.

\section{Figure 7}

Foreign-Language Skills of the Immigrant Population, \%

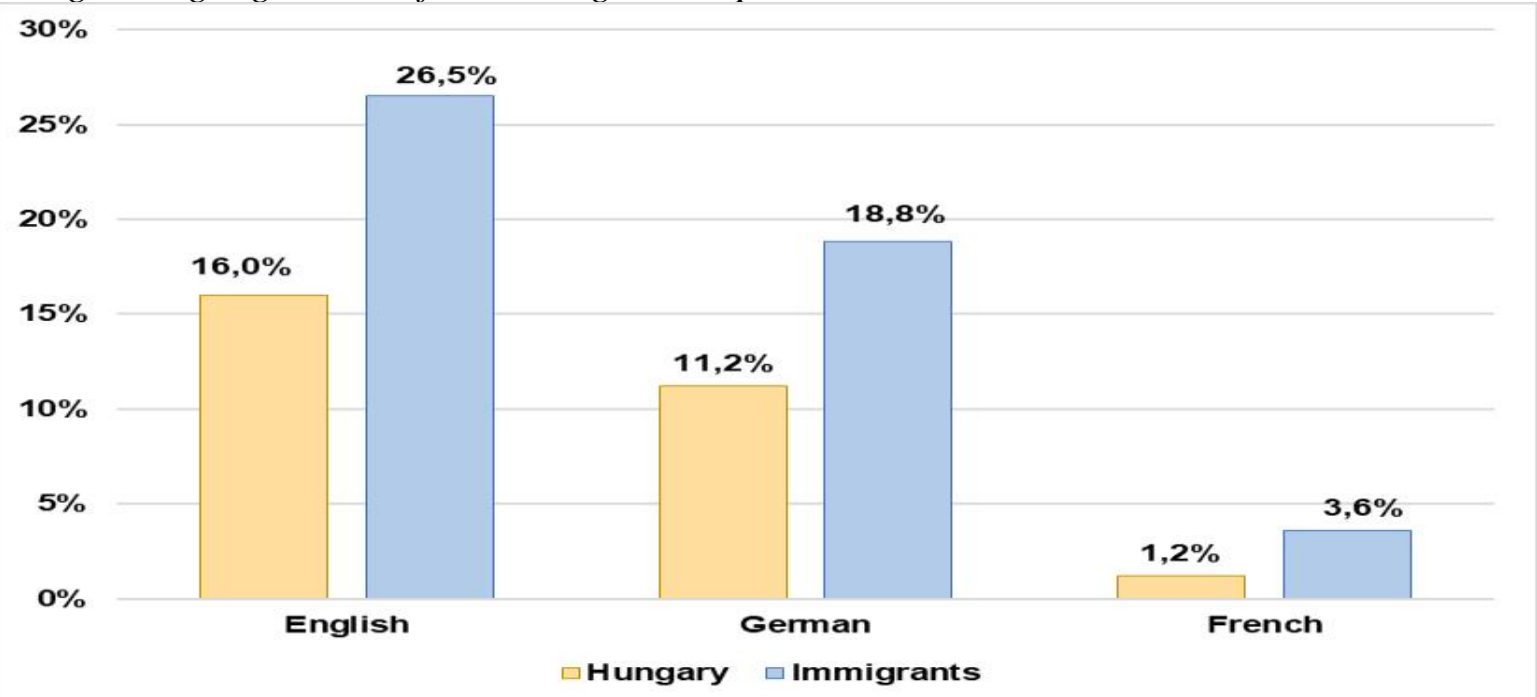

Note. Source: Hungarian population census data 2011. Copyright 2021 by HCSO \& RINS.

Unlike in Western Europe, immigrants in Hungary and in CEE are not at a disadvantage compared to the host population (Gödri, 2010). Our post 1985 ethnocentric immigrants have similar features:

- The employed are overrepresented in age group 15-64 (Figure 8). In addition to the identical linguistic and cultural background, favorable age structure and closely related economic activity may play a major role.

- The employment rates for various sectors do not differ significantly between the ethnocentric immigrant and total population. The largest difference is in public 
administration, where the proportion of immigrants is only 5\% (Hungarian: 9\%). Immigrants' training and work experience outside Hungary may be less adaptable to the Hungarian administrative work environment, or well-educated immigrants may earn more outside the public sector.

- The occupational structure of the age group 15-64 is similar among the Hungarian resident population and ethnocentric immigrants in the case of both genders. Most of the employed population in Hungary aged 15-64 work in occupations requiring a tertiary or secondary education $(17 \%)$, while immigrants $(21 \%)$ are more likely to have occupations requiring a tertiary education. Moreover, occupations requiring higherlevel qualifications are more common among immigrants.

However, in the case of this indicator, the over-representation of immigrants is perhaps more moderate than in the case of education. This may also indicate that some immigrants are unable to utilize their higher education qualifications in the Hungarian labor market, which may be related to the recognition of qualifications or migration motivations and life strategies (they may be more inclined to choose to run a business rather than becoming an employees). However, immigrants are not lagging in this field, because $60.3 \%$ of those with a university or college degree work in jobs requiring tertiary education, which is almost $4 \%$ higher than the total figure in Hungary.

\section{Figure 8}

Distribution of Population Aged 15 and Over by Economic Activity, \%

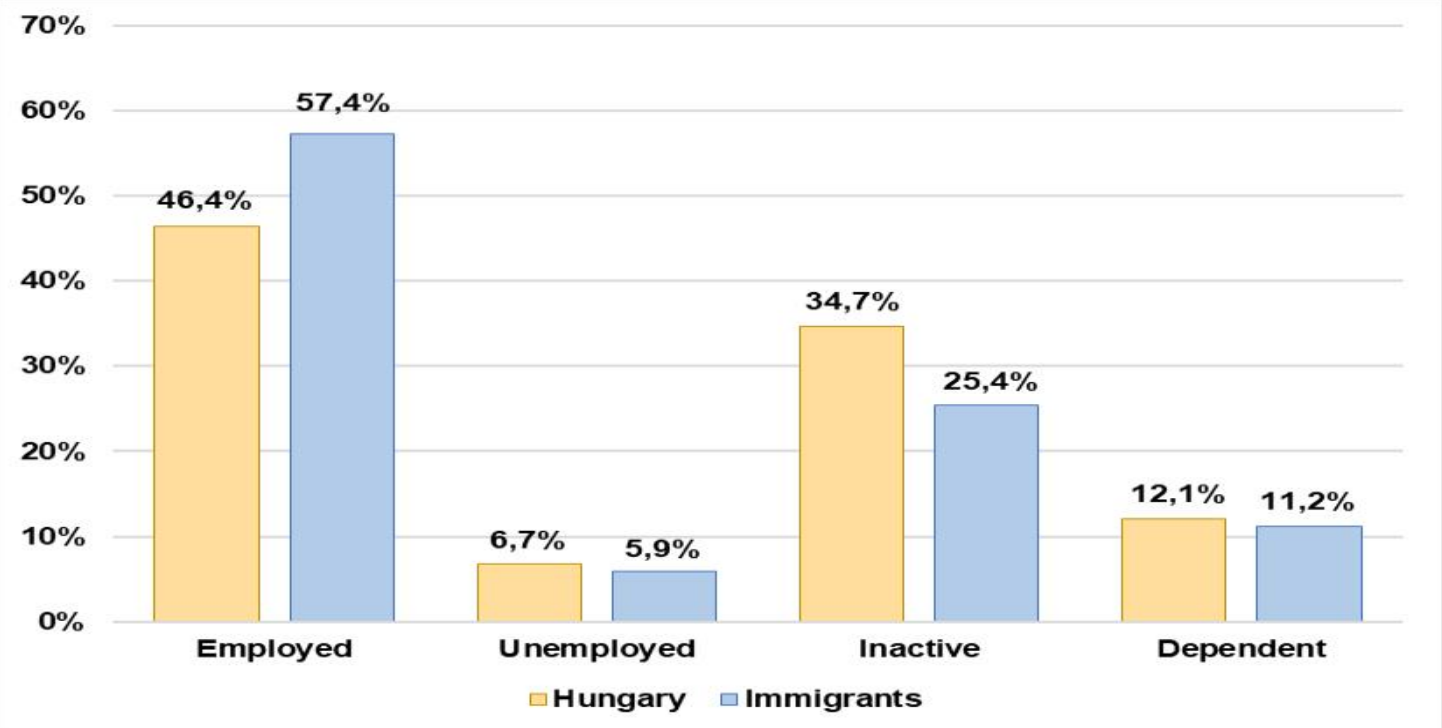

Note. Source: Hungarian population census data 2011. Copyright 2021 by HCSO \& RINS.

A separate analysis focused on some occupations requiring higher education, most of which are shortage professions.

- Ethnocentric immigrants were over-represented in all nine shortage professions involved in the study (physician, dentist, veterinary surgeon, engineer, IT specialist, teacher, lawyer, and other secondary and tertiary workers), which are important for the national economy and social well-being. This is not at all surprising given their qualification structure. However, for some professions, the degree of overrepresentation is almost staggering (e.g. dentist, doctors) (Figure 9). 
- The prevalence of these selected occupations is also shown (Figure 10). The share of immigrants is greater for each examined profession (especially among physicians). This situation represents a serious loss for the communities of origin.

- Ethnocentric immigrants arriving after the age of 21 in these selected occupations were specifically examined as they are most likely to earn qualifications before migration, indicating not only additional human resources but also significant savings on human resource investment for Hungary. The proportion of those who obtained their degrees after immigration varies between $40 \%$ (lawyers and IT specialists) and $6.7 \%$ (veterinarians). It also worth mentioning that the engineers, physicians, and IT specialists are among the top professions in Hungary that struggle with a labor shortage.

\section{Figure 9}

The Proportion of Immigrant Population in Certain Professions, \%

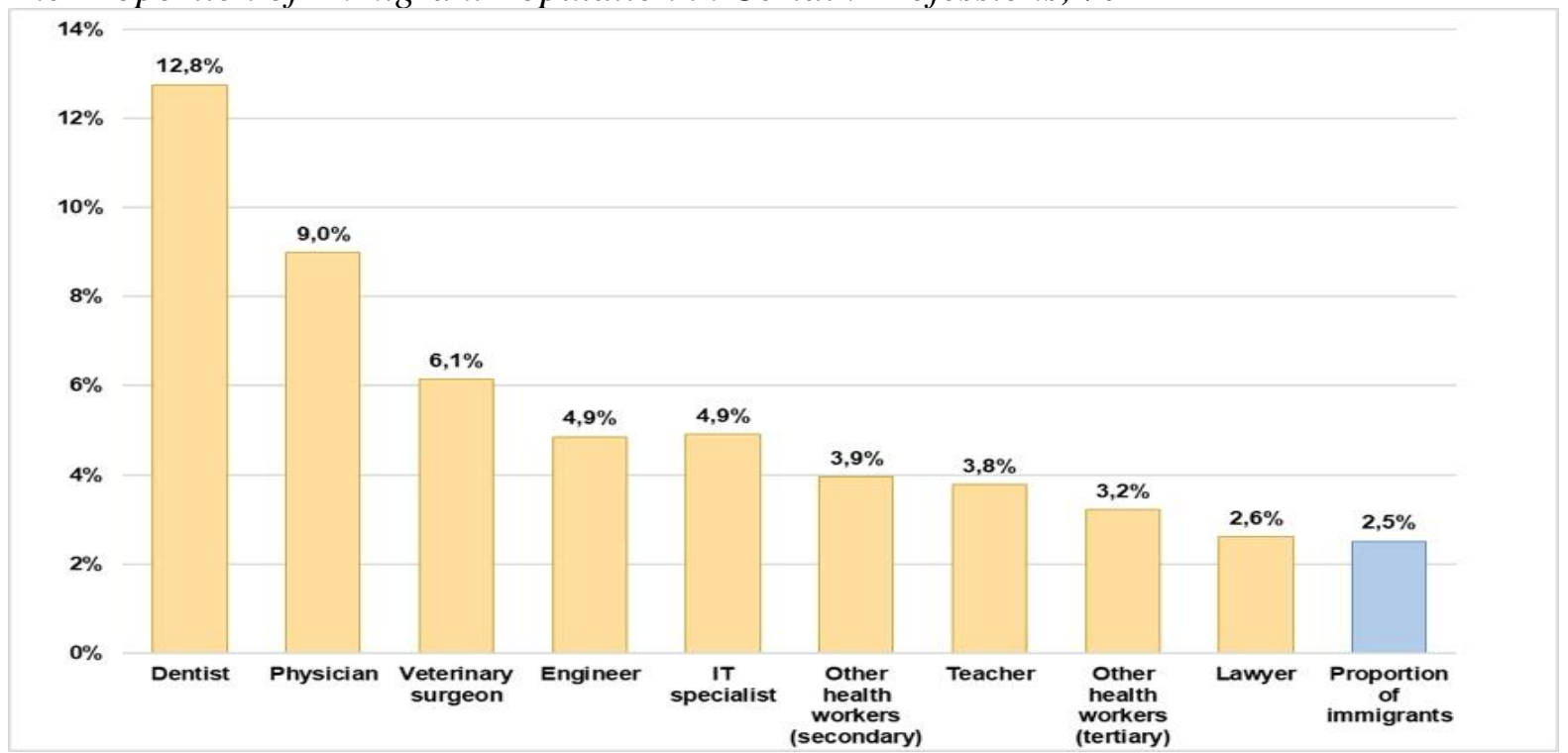

Note. Source: Hungarian population census data 2011. Copyright 2021 by HCSO \& RINS.

\section{Figure 10}

Population per Thousand Persons in Some Selected Occupations, Persons

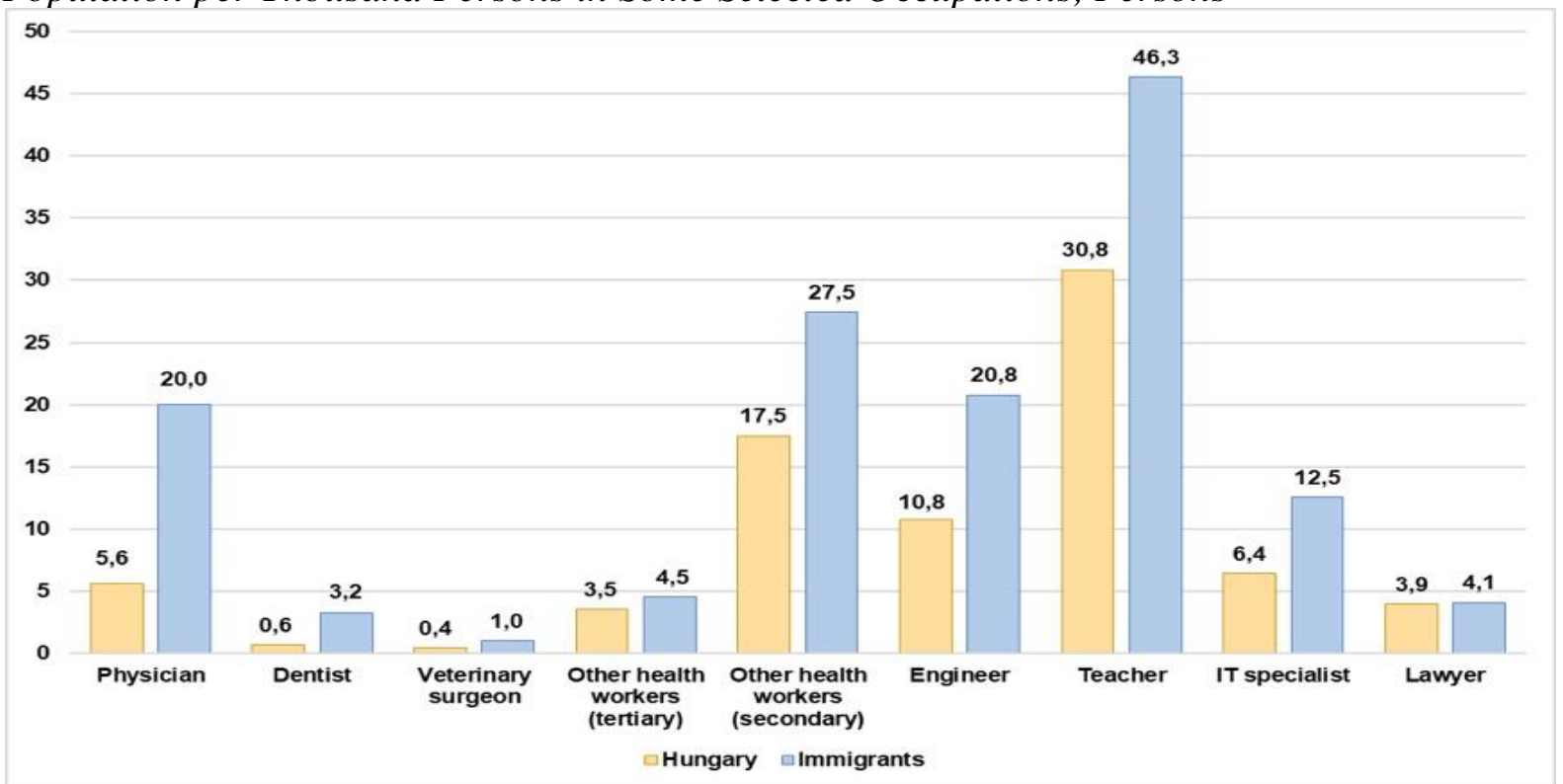

Note. Source: Hungarian population census data 2011. Copyright 2021 by HCSO \& RINS. 
Péti, M.

\section{Changes in Native Hungarian Communities Abroad}

Examining the emitting regions of immigration - the ethnic Hungarian minority communities - has not been covered in the present research, but other studies have already addressed this topic. The significant quantitative (demographic) and even more significant qualitative (human-resource-related) added value in Hungary due to migration of these populations has obviously caused extremely severe losses for these communities abroad (e.g. Kapitány, 2013). The significant aging experienced in almost all ethnic Hungarian communities in neighboring countries can be attributed to this.

This may be one of the reasons why the intensity of this ethnocentric immigration is probably not sustainable, and its continuation may lead to more significant losses at an increasing speed. According to the present research, the large-scale loss of trained people - i.e., intense 'brain drain' - can also be reasonably assumed. This might be challenging for Hungary's kin-state politics on maintaining native Hungarian minority communities abroad (Kántor, 2014).

\section{The Impact of Ethnocentric Immigration Through Population Projections}

After describing the characteristics of the immigrant population, questions arose about its quantifiable effects on the population of Hungary as experienced in the past, and its future potential. Therefore, population projections were made in the frame of this research. Three hypotheses/research questions were formulated for the future:

- What will the population of Hungary be by 2060 if fewer people immigrate in frame of ethnocentric migration (see in this case: immigration from neighboring countries of Hungary with more than 100,000 ethnic Hungarians: Serbia, Romania, Ukraine and Slovakia) than assumed in the official population projection made in 2015?;

- What will the population of Hungary be by 2060 if only the number of people who immigrate from Ukraine increases, compared to the official population projection (due to probable but hypothetical political and economic crises)?;

- What will the population of Hungary be by 2060 if more ethnocentric immigrants arrive (from four countries see above) than assumed in the official population projection?

The development of these three future scenarios was based on a consensus that emerged among professional demographers and decision-makers. Naturally, these findings can only be considered hypotheses as they have been scarcely explored empirically - and if so, mostly only through case studies. The hypothetical processes reflected in these scenarios are based on relatively new phenomena that had not emerged at the time of the 2011 census. Investigating these new features will probably be challenging even after 2011 or through a new census because of data collection and public-administration-related concerns. Due to the increasingly widespread phenomenon of dual citizenship among minority ethnic Hungarian groups, censuses will not necessarily be able to fully inform us about these phenomena. The intensive uptake of dual citizenship in 2010 also makes it difficult to identify real geographical mobility processes through register data.

One of the most important consensual observations is that the wave of ethnocentric immigration from neighboring countries to Hungary slowed down in the 2010s. The emissive capacity of ethnic Hungarian communities decreased significantly even since 2011 (Kapitány, 2013). Migration destinations in Western Europe are becoming more and more attractive for ethnic Hungarians (Papp, 2017), and their dual citizenship provides a better access to the Western European labour market (Gödri, 2015; Péti et al., 2018). 
Social, economic, and political reasons for immigration may also significantly change the development of scenarios. Most ethnocentric immigrants came from Romania during the time of persecution and economic crises of the 1980s and 1990s, or from Yugoslavia during the civil wars of 1990s. The impact of new economic and lifestyle opportunities can also be observed: cross-border employment and commuting or urban development (agglomeration) may have contributed to the rise of immigration to areas adjacent to Romania and Slovakia since the 2000s (Péti et al., 2018). At present, however, it is worthwhile considering scenarios that will bring about significant change, especially in the case of Ukraine. This state, due to geopolitical reasons is generally unstable, and presents a risk of mass emigration (Legucka et al., 2021). Besides deep overall Ukrainian political and economic crisis compounded by armed conflict, political tensions between the government and the ethnic Hungarian community have also emerged recently. Data supply from this region is poor because the 2011 census was cancelled, although a Hungarian study partially remedied this (Tátrai et al., 2018). However, based on the available data and consensus experience, significant permanent or temporary outflow is likely, in which not only Hungarian immigrants will participate in large numbers.

Scenarios along hypothesizes:

1. According to the first hypothesis, the number of ethnocentric immigrants from neighboring countries will decrease compared to the previous period - namely the immigration of young people (under 15 years old) and working age people (15-64 years old) from neighboring countries will decrease in 2017 to $75 \%$ of the average of the last 30 years (1985-2015), later to 50\% (in 2018), to $25 \%$ (in 2019), and to $10 \%$ in 2020; and will remain at the latter level from 2021 to 2060. The change in the proportion of elderly immigrants (over 65 years old) follows that of young and working age people with a five-year lag. Compared to the other two hypotheses and the official population projection, this also results in the most unfavorable demographic situation. According to this, the proportion and number of young and active people is lowest in this scenario, and that of the elderly is the highest. The country's population will decrease to seven million by 2060 . The proportion of young people will decrease from $14.5 \%$ to $13.3 \%$ compared to 2016; the proportion of the active age population will fall from $67 \%$ to $51.6 \%$; while the proportion of the elderly will increase from $18.5 \%$ to $35 \%$. While according to the official population projection, the population will be 7.9 million by 2060 , the proportion of people under 15 will be $13 \%$, the working age population is projected to be $54.1 \%$, while the proportion of elderly is expected to be $33 \%$ (Földházi, 2015). There will be a more even distribution of genders and age groups, with a larger number of older age groups and a slight increase in the number of people moving towards old age. In addition, we can expect a slight surplus in the number of women and also the elderly, to an increasing extent. These latter trends are similar in the following other two scenarios too, with only minor changes in the number of migrants that are expected.

2. The starting point of the second hypothesis is that only the number of immigrants from Ukraine will increase compared to the previous situation (not exclusively ethnocentric migrants). According to this scenario, the number of arrivals from Ukraine will increase significantly by 2026 (in total, 290,000 people will arrive in Hungary), and after 2026 migration trends will follow the official population projection. This scenario results in a more moderately aging population, and the country's total population will remain above eight million by 2060 . A rise of two percentage points will be seen for the active and elderly and of 0.2 percentage points for juveniles compared to in the first hypothesis. 
3. The third hypothesis is that more ethnic Hungarian people from neighboring countries will immigrate compared to the official population projection. According to this scenario, the immigration of young people (under 15 years of age) and people of working age (15-64 years old) from the four countries together will increase in 2017 to $110 \%$ of the average of the last 30 years (1985-2015); later to $120 \%$ (in 2018), 130\% (in 2019), and $150 \%$ in 2020; remain at the latter level from 2021 to 2030; and from then on will fall steadily back to the average level of the last 30 years in five years' time (in line with the probable disappearance of the ability of ethnic Hungarian minority communities to emit emigrants) and remain so until 2060. Older immigrants (65+) follow young and working age people with a lag of five years, but the proportions and trends are the same for them. If this hypothesis is realized, the total population of Hungary would be 7.67 million in 2060, thus the scenario leads to a lower population than the official population projection, despite the initial increase in immigration. This is mainly because the official population projection assumes a gradually increasing positive migration balance from 2035 (not calculating with ethnocentric migrants, but others), as opposed to our hypothesis. However, the results of this third hypothesis come closest to the official population projection both in terms of population and number of births and deaths (Figure 11).

\section{Figure 11}

Baseline Model of the Official Population Projections of the HDRI and Three Versions of the Hypothetical Forecast, Persons

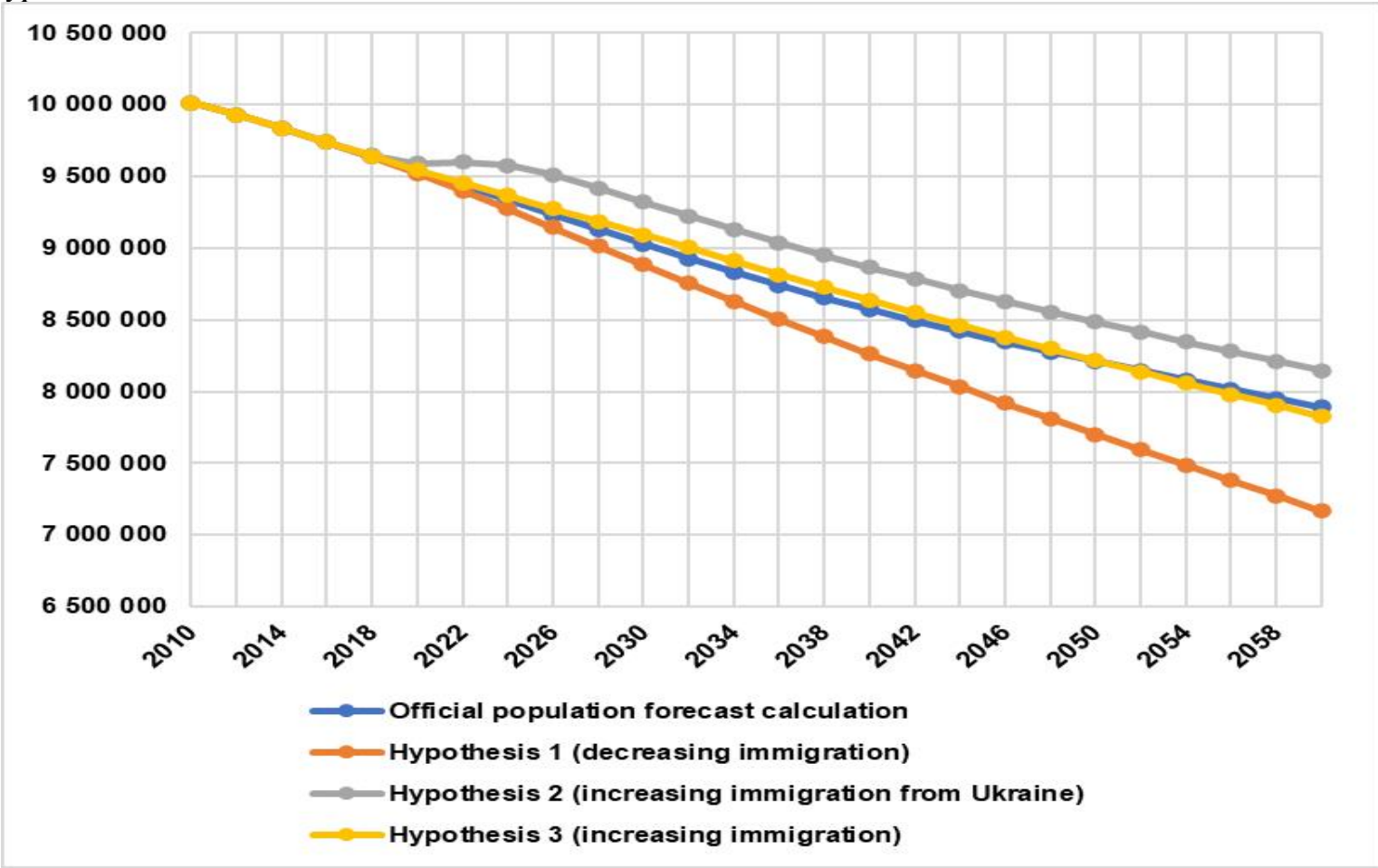

Note. Source: Hungarian official population projection data 2015. Copyright 2021 by HDRI \& RINS.

The question also arises: how would Hungary's population have changed if no ethnocentric immigration had taken place since the 1980s. If those who had immigrated from neighboring countries were not included in the population, the population would have decreased by an average of 33,500 people per year between 1990 and 2011, and by 56,000 between 2011 
and 2015. Thus, the population would have fallen below 10 million as early as in 2003 (Figure 12). In actual fact this happened only by 2011.

\section{Figure 12}

Population Trends in Reality and Without the Immigration from the Four Neighboring Countries, Persons

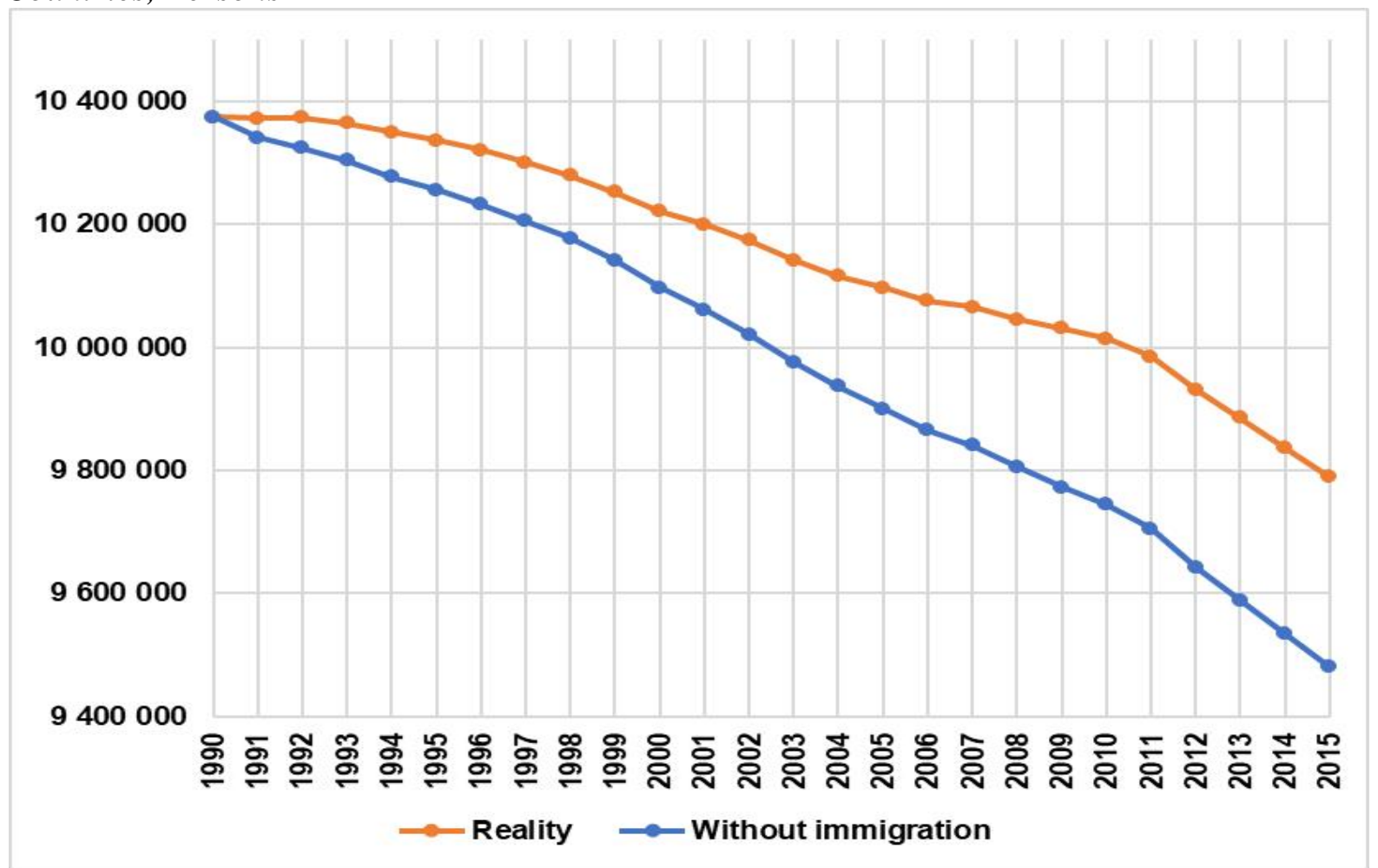

Note. Source: Hungarian official population projection data 2015. Copyright 2021 by HDRI \& RINS.

\section{Conclusions and Discussions}

Ethnocentric migration takes place between communities sharing the same ethnic background. Cultural relations or similar identity patterns can stimulate this process. It has become an emblematic type of migration in CEE since the 1980s between ethnic minority communities and kin-states driven by various motivations (e.g. work, family, avoiding repression). Still, it has been studied less intensively than the other emblematic migration process of CEE: the emigration to Western Europe. This study maps ethnocentric migration in Hungary which is probably one of the most significant ethnocentric type of migration processes in CEE.

According to our definition, ethnocentric migration in Hungary takes place when ethnic Hungarians living outside of Hungary move to Hungary. This definition was applied on the dataset of the 2011 Hungarian census. Due to the former changes of the Hungarian state border, ethnic Hungarians who were born outside of Hungary and have moved to Hungary since 1985 were involved in our analysis (patterns of former internal migration have to be excluded). 1985 is also a starting point of mass migration to Hungary from the co-ethnic minority communities triggered by political and economic crises.

This study searched for the main quantitative demographic parameters of the community of ethnocentric migrants in Hungary. Another research question of this study is how the demography of Hungary would change if there were a change in this wave of immigration. These quantitative parameters can be detected as follows: 
- This ethnocentric immigration involves a community of about 250,000 people. Together with their descendants who have already been born in Hungary, is estimated at around 315,000 people.

- According to a reverse population projection, it is due to ethnocentric immigrants that the population of Hungary dropped below 10 million only in 2011; otherwise, this would have happened in 2003.

- If the intensity of immigration decreases - which is a realistic assumption due to the other accessible European destinations being more attractive than Hungary and the expiring demographic resources of the ageing minority communities - it may affect the population of Hungary highly unfavorably. Compared to a baseline scenario involving the population projection of Hungary from 2015 and taking into account a sharp decrease in ethnocentric immigration, it may lead to a decline in the population of up to 700,000 by 2060 .

Potentials of ethnocentric migrants in influencing social and economic processes of Hungary were also investigated through the community's human resource parameters. This migrant population contributed probably even more to the quality parameters of the country's human resources than to its quantitative characteristics:

- The economic activity and education of this population are rather higher than that of the total Hungarian population.

- Furthermore, knowledge of foreign languages is more common among this group. With a little exaggeration, the speakers of the official languages of neighboring countries are almost all members of this community.

- Important intellectual fields (e.g., health, pedagogy, technical, and IT fields) are highly over-represented to such an extent that certain Hungarian professions are considerably populated by members of this community.

The Hungarian community of ethnocentric immigrants is generally similar to other immigration communities in CEE and differs from Western European ones. The social status of this population is high, and it cannot be characterised by problems related to economic integration. The added value of this population in Hungary is critical: the country needs immigrants, both demographically and in terms of human wealth.

The Hungarian case discussed in the study might be one of the most significant ones in CEE, still is only one case among the potentially many other ethnocentric migration flows of CEE. However, this current study may prove the importance and relevance of doing more research on ethnocentric migration patterns in CEE. Emigration to Western Europe is not the sole concern in describing demographic processes of this macroregion, and the emerging migration between CEE countries is highly influenced by ethnocentric features. The future significance of this issue can be estimated also from a migration policy point of view. Unlike in Western Europe, national policies in CEE rather discourage immigration, but ethnocentric ways are encouraged in many CEE countries. This policy approach is relevant not only in the context of CEE or Europe, but also on a global level, especially in the case of geopolitical hotspots. Therefore, there is a need for further comprehensive studies on ethnocentric migration to understand and predict CEE and global migration processes.

The importance of ethnocentric migration in CEE can be underlined by the fact that large ethnic minority communities still exist in this macroregion: besides Hungarians among many others e.g. Russians, Poles, Serbs, Croats, Albanians, Romanians and Moldavians sharing Romanian identity patterns, Bulgarians and Macedonians, and even Germans. Under the current 
geopolitical circumstances, relations between these communities sharing similar identity patterns can be seriously affected by security and economic crises (which can also be related to the pandemic) or emerging policies on identity forming. Intentions to leave minority communities and move to kin-states can emerge unexpectedly.

It is also worth discussing that an overheated Ethnocentric migration can harm the demographic structure of the emitting ethnic communities. It has already happened sometimes in the past (e.g. most native Germans communities of CEE faded away), but can be assumed in the Hungarian case as well. So ethnocentric migration can challenge kin-states' policies on maintaining the already heavily endangered native co-ethnic communities abroad. On the other hand, vanishing native minority communities should be considered as a cultural loss not only for the given ethnic community but also for the host country and for the European culture.

\section{Funding Details}

This work was supported by the European Social Fund under Grant EFOP 3.10.1-172017-00002 and Grant EFOP 1.12.1-17-2017-00003.

\section{Disclosure Statement}

The authors report no potentially competing interests.

\section{References}

Bába, Sz. (2015). Az óperenciás tengeren túl. Magyar identitás a diaszpórában. Nemzetstratégiai Kutatóintézet - Méry Ratio Kiadó.

Blaskó, Zs., \& Gödri, I. (2014). Kivándorlás Magyarországról: Szelekció, célországválasztás az „új migránsok” körében. Demográfia, 57(4), 271-307. https://demografia.hu/kiadvanyokonline/index.php/demografia/article/view/2636/2488

Bottoni, S. (2017). Finding the enemy: Ethnicized state violence and population control in Ceaușescu's Romania. Journal of Cold War Studies, 19(4), 113-136. https://doi.org/10.1162/jcws_a_00766

Brunarska, Z., \& Lesińska, M. (2014). Poland as a(n) (un)attractive destination for Belarusian labour migrants: CARIM-East research report (CMR Working Papers, No. 70/128). University of Warsaw, Centre of Migration Research. https://www.econstor.eu/bitstream/10419/140853/1/784959781.pdf

Brunarska, Z., Kindler, M., Szulecka, M., \& Toruńczyk-Ruiz, S. (2016). Ukrainian migration to Poland: A "local" mobility? In O. Fedyuk \& M. Kindler (Eds.), Ukrainian migration to the European Union lessons from migration studies (pp. 115-133). IMISCOE Research Series, Centre of Migration Research, Springer Open. https://doi.org/10.1007/978-3-319-41776-9

Ciobanu, R. O. (2015). Multiple migration flows of Romanians. Mobilities, 10(3), 466-485. https://doi.org/10.1080/17450101.2013.863498

Coleman, D. (2009). Divergent patterns in the ethnic transformation of societies. Population \& Development Review, 35(3), 449-478. https://doi.org/10.1111/j.17284457.2009.00293.x

Council of Europe. (2015). Languages covered by the European Charter for Regional or Minority Languages - European Council: European Charter for Regional or Minority Languages.

COE. http://www.coe.int/t/dg4/education/minlang/AboutCharter/LanguagesCovered.pdf 
Croitoru, A. (2021). Stimulating return migration to Romania: A multi-method study of returnees' endorsement of entrepreneurship policies. Journal of Contemporary European Studies, 29(2), 264-281. https://doi.org/10.1080/14782804.2020.1824896

Cseh Papp, I., Bilan, S., \& Dajnoki, K. (2018). Globalization of the labour market - Circular migration in Hungary. Journal of International Studies, 12(2), 182-200. https://doi.org/10.14254/2071-8330.2019/12-2/11

DeWaard, J., \& Raymer, J. (2012). The temporal dynamics of international migration in Europe: Recent trends. Demographic Research, 26, 543-592. https://doi.org/10.4054/DemRes.2012.26.21

Drinkwater, S., \& Garapich, M. P. (2015). Migration strategies of Polish migrants: Do they have any at all? Journal of Ethnic \& Migration Studies, 41(12), 1909-1931. https://doi.org/10.1080/1369183X.2015.1027180

Dumbrava, C. (2018). The ethno-demographic impact of co-ethnic citizenship in Central and Eastern Europe. Journal of Ethnic \& Migration Studies, 45(6), 958-974. https://doi.org/10.1080/1369183X.2018.1440490

Földházi, E. (2015). Structure and future of Hungary's population. In J. Monostori, P. Öri, \& Zs. Spéder (Eds.), Demographic portrait of Hungary 2015 (pp. 211-224). KSH NKI. https://www.demografia.hu/en/publicationsonline/index.php/demographicportrait/artic le/view/893/655

Frejka, T., \& Gietel-Basten, S. (2016). Fertility and family policies in central and eastern Europe after 1990. Comparative Population Studies, 41(1), 3-56. https://doi.org/10.12765/CPoS-2016-03

Gödri, I. (2010). Bevándorlás és etnicitás - Összefüggések nyomában. In Á. Hárs \& J. Tóth (Eds.), Változó migráció - változó környezet (pp. 87-124). MTA Nemzeti-etnikai Kisebbségkutató Intézet. https://kisebbsegkutato.tk.hu/uploads/files/archive/65.pdf

Gödri, I. (2015). International migration. In J. Monostori, P. Öri, \& Zs. Spéder (Eds.), Demographic portrait of Hungary 2015 (pp. 185-209). KSH Népességtudományi Kutatóintézet.

https://www.demografia.hu/en/publicationsonline/index.php/demographicportrait/artic le/view/892/662

Grieveson, R. (2019). Moving into the slow lane - Economic analysis and outlook for central, east and southeast Europe. Forecast Report Spring 2019. The Vienna Institute for International Economic Studies. https://wiiw.ac.at/moving-into-the-slow-lane-dlp4824.pdf

HCSO \& RINS. (2021). Hungarian population census data 2011 by Hungarian Central Statistical Office (HCSO) filtered by Research Institute for National Strategy (RINS) [Statistics database].

HDRI \& RINS (2021). Hungarian official population projection data 2015 by Hungarian Demographic Research Institute (HDRI) filtered by Research Institute for National Strategy (RINS) [Statistics database].

Heleniak, T. (2001). Migration and restructuring in post-Soviet Russia. Demokratizatsiya, 9(4), 531-549. https://demokratizatsiya.pub/archives/09-4_Heleniak.PDF

Horáková, M. (2000). Legal and illegal labour migration in the Czech Republic: Background and current trends. In International Migration Papers 32, Informal Network on Foreign Labour in Central And Eastern Europe. International Migration Branch International Labour Office, Geneva (Ilo/Luxemburg Co-Operation: Project Rer/97/Mo2/Lux). https://www.ilo.org/wcmsp5/groups/public/---ed_protect/---protrav/--migrant/documents/publication/wcms_201877.pdf

https://doi.org/ 10.1556/2065.182.2021.6.4 
Jaroszewicz, M. (2018, October). Migration from Ukraine to Poland - The trend stabilises [OSW Report]. Centre for Eastern Studies. https://core.ac.uk/download/pdf/162642923.pdf

Kaczmarczyk, P. (2010). Brains on the move? Recent migration of the highly skilled from Poland and its consequences. In R. Black, G. Engbersen, M. Okólski, \& C. Panţîru, (Eds.), A continent moving west? (pp. 165-164). Amsterdam University Press. https://doi.org/10.1515/9789048510979-008

Kaczmarczyk, P., Aldaz-Carroll, E., \& Hołda, P. (2020). Migration and socio-economic transition: Lessons from the Polish post-EU accession experience. East European Politics \& Societies, 34(4), 910-936. https://doi.org/10.1177/0888325420902238

Kántor, Z. (2014). Hungary's kin-state politics 2010-2014. Minority Studies, 17. https://bgazrt.hu/minority-studies-17-szam/

Kapitány, B. (2013). Kárpát-medencei népszámlálási körkép. Demográfia, 56(1), 25-64. https://demografia.hu/kiadvanyokonline/index.php/demografia/article/view/368/601

Kapitány, B., \& Spéder, Zs. (2015). Gyermekvállalás. In J. Monostori, P. Öri, \& Zs. Spéder (Eds.), Demográfiai portré 2015 - Jelentés a magyar Népesség helyzetéről (pp. 41-56). KSH Népességtudományi Kutatóintézet. https://demografia.hu/kiadvanyokonline/index.php/demografiaiportre/article/view/246 $6 / 2472$

Kincses, Á. (2015). A nemzetközi migráció Magyarországon és a Kárpát-medence magyar migrációs hálózatai a 21. Század elején. Központi Statisztikai Hivatal. http://real.mtak.hu/26456/1/muhelytanulmanyok8.pdf

Kincses, Á., \& Tóth, G. (2019). A Magyarországon élő külföldi kötődésű népesség térbeli autokorreláltsága. Területi Statisztika, 59(6), 579-606. https://doi.org/10.15196/TS590601

Kiss, T. (2014). Etnikai rétegződési rendszer Erdélyben és Romániában. A magyarok társadalmi pozíciói. $\quad$ Regio, $22(2), \quad 187-245$. https://regio.tk.mta.hu/index.php/regio/article/view/28/pdf_6

Legucka, A., Benedyczak, J., Legieć, A., Piechowska, M., Pieńkowski, J., \& Szeligowski, D. (2021). Responses, resilience, and remaining risks in the eastern neighbourhood evidence from radicalization and migration (EU-LISTCO Working Paper Series No. 11). EU Listco. http://dx.doi.org/10.17169/refubium-30545

Lutz, W. (2010). Emerging population issues in Eastern Europe and Central Asia. Research gaps on demographic trends, human capital and climate change. UNFPA. https://www.unfpa.org/publications/emerging-population-issues-eastern-europe-andcentral-asia

Matusz, P., Aivaliotou, E., \& Przytuła, S. (2020). Multiple faces of the migration crisis. In S. Przytuła \& L. Sułkowski, (Eds.), Integration of migrants into the labour market in Europe (Advanced Series in Management, Vol. 25) (pp. 3-14). Emerald Publishing Limited. https://doi.org/10.1108/S1877-636120200000025002

Matzhanova, I., \& Simtikov, Z. (2021). Stratification of youth employment and departure abroad with the purpose of work: Kazakhstan and neighbouring countries. Journal of Ethnic \& Cultural Studies, 8(3), 95-112. http://dx.doi.org/10.29333/ejecs/792

Molodikova, I. (2007). Transformation of migration patterns in post-Soviet space: Russian New Migration Policy of "Open Doors" and its effect on European migration flows. Review of Sociology, 132, 57-76. https://szociologia.hu/dynamic/RevSoc_2007_2_MolodikovaI_Transformation.pdf

Papp, Z. A. (2017). Változó kisebbség: Kárpát-medencei magyar fiatalok A GeneZYs 2015 kutatás eredményei. Mathias Corvinus Collegium - Tihanyi Alapítvány - MTA. https://kisebbsegkutato.tk.hu/uploads/files/Genezys_-_kifuto_nelkul.pdf 
Peshkopia, R., Kosovare Bllaca, L., \& Lika, J. (2021). Individual similarities and regional differences: The impact of 2015 refugee crisis on Europeans' attitudes toward immigration. European Politics \& Society. https://doi.org/10.1080/23745118.2021.1927375

Péti, M. (2017). Nem magyar nemzetiségü kárpát-medencei áttelepülők Magyarországon. Áttelepülésük jellemzői, letelepedésük területisége, lehetséges hatásuk az őshonos nemzetiségi közösségeinkre. Demográfia, 60(1), 57-103. https://doi.org/10.21543/dem.60.1.2

Péti, M., Csata, Zs., Schwarcz, Gy., \& Borbély, M. (2021). How Do Hungarians Live? A Comprehensive Study on the Quality of Life of the Hungarians in the Carpathian Basin. Magyar Tudomány, 182(6), 755-768.

Péti, M., Szabó, B., \& Szabó, L. (2018). Spatial pattern of immigrant population from countries of the Carpathian Basin to Hungary. A Kárpát-medence országaiból Magyarországra áttelepült népesség területi mintázata. Területi Statisztika, 57(3), 311-350. https://doi.org/10.15196/TS570304

Piatkowsky, M. (2013). Poland's new golden age: Shifting from Europe's periphery to its center (Working Paper No. 6639). Policy Research, World Bank. https://openknowledge.worldbank.org/bitstream/handle/10986/16856/WPS6639.pdf?s equence $=1 \&$ is Allowed $=\mathrm{y}$

Průchová Hrůzová, A. (2021). What is the image of refugees in Central European media? European Journal of Cultural Studies, 24(1), 240-258. https://doi.org/10.1177/1367549420951576

Raduaiki, N. (2016). Refugees from Bosnia and Herzegovina in Serbia: Socio-demographic characteristics, status and prospects. In M. Valenta \& S. P. Ramet (Eds.), The Bosnian diaspora integration in transnational communities. Routledge. https://www.routledge.com/The-Bosnian-Diaspora-Integration-in-TransnationalCommunities/Valenta-Ramet/p/book/9781138277106

Rees, P., van der Gaag, N., de Beer, J., \& Heins, F. (2012). European regional populations: Current trends, future pathways, and policy options. European Journal of Population, 28(4), 385-416. https://doi.org/10.1007/s10680-012-9268-z

Salamin, G. (2015a). Transforming regional position of Central-Eastern Europe in the economic space of the European Union with special reference to Hungary. Hungarian Studies, 29(1-2), 73-91. https://doi.org/10.1556/044.2015.29.1-2.6

Salamin, G. (2015b). Changing spatial dimensions in the current economic development of the European Union. In G. Salamin (Ed.), Cities in action reflecting global economic challenges and technological trends with special reference to the smart city concept (pp. 29-46). Hungarian Society for Urban Planning. https://www.mut.hu/?module=news\&action=getfile $\&$ fid $=217486$

Schneider, O. (2021). Labor migration in the European Union: The case of central and eastern Europe (Working Papers, 23/2021). IES FSV, Charles University. https://ies.fsv.cuni.cz/sci/publication/show/id/6454/lang/en

Simionescu, M. (2016). Macroeconomic determinants of permanent emigration from Romania - A Bayesian approach. Journal of International Studies, 9(2), 170-180. https://doi.org/10.14254/2071-8330.2016/9-2/13

Smętkowski, M. (2018). The role of exogenous and endogenous factors in the growth of regions in central and eastern Europe: The metropolitan/non-metropolitan divide in the pre- and post-crisis era. European Planning Studies, 26(2), 256-278. https://doi.org/10.1080/09654313.2017.1361585 
Strey, A., Fajth, V., Dubow, T. M., \& Siegel, M. (2018). Determinants of migration flows within the EU - Literature review. Maastricht University, REMINDER Project. https://doi.org/10.1080/09654313.2017.1361585

Strockmeijer, A., de Beer, P., \& Dagevos, J. (2019). Should I stay or should I go? What we can learn from working patterns of central and eastern European labour migrants about the nature of present-day migration. Journal of Ethnic \& Migration Studies, 45(13), 24302446. https://doi.org/10.1080/1369183X.2018.1562326

Tabac, T., \& Gagauz, O. (2020). Migration from Moldova: Trajectories and implications for the century of origin. In M. Denisenko, S. Strozza, \& M. Light (Eds.), Migration from the newly independent states - 25 years after the collapse of the USSR - Societies and political orders in transition (pp. 143-169). Springer Nature. https://doi.org/10.1007/978-3-030-36075-7

Tátrai, P., Molnár, J., Kovály, K., \& Erőss, Á. (2018). Changes in the number of Hungarians in Transcarpathia based on the survey 'SUMM A 2017'. Hungarian Journal of Minority Studies, 2, 103-135. https://bgazrt.hu/wp-content/uploads/2019/10/7.Tatrai_et.al_.pdf

Török, I. (2017). Migration patterns and core-periphery relations from the central and easternEuropean perspective. European Review, 25(3), 388-405. https://doi.org/10.1017/S1062798717000059

Valenta, M., Mesic, M., \& Strabac, Z. (2016). Bosnian Croats in Croatia: 'ethnically privileged migrants', 'culturally distant co-ethnics' or 'Croats as any other Croats'? In M. Valenta \& S. P. Ramet (Eds.), The Bosnian diaspora integration in transnational communities. Routledge. https://www.routledge.com/The-Bosnian-Diaspora-Integration-inTransnational-Communities/Valenta-Ramet/p/book/9781138277106

Wallace, C. (2002). Opening and closing borders: Migration and mobility in east-central Europe. Journal of Ethnic \& Migration Studies, 28(4), 603-625. https://doi.org/10.1080/1369183021000032227

Wallace, C., \& Patsiurko, N. (2017). Relational identities on EU borderlands: The case of Poles in Belarus and Belarusians in Poland. Ethnic \& Racial Studies, 40(1), 77-95. https://doi.org/10.1080/01419870.2016.1201582

Zubíková, A. (2019). Integration of immigrants in the EU_15: Success or failure? In K. Cermakova, S. Mozayeni, \& E. Hromada (Eds.), Proceedings of the 12th economics \& finance conference (pp. 367-384). International Institute of Social and Economic Sciences. https://doi.org/10.20472/EFC.2019.012.025 
Péti, M.

\section{Notes on Contributors}

Márton Péti, $\mathrm{PhD}$, is an associate professor at Corvinus University of Budapest, and a researcher at the Research Institute for National Strategy in Hungary. His main research interest is the regional and ethnic geography of Central Europe, territorial governance, development policies, and planning for sustainable development.

Laura Szabó, $\mathrm{PhD}$, is a research fellow in the Hungarian Demographic Research Institute. Her main demographic research topic is fertility, childlessness, and ethnic demography, Central and Eastern European Roma minority, research methodology, longitudinal birth cohort survey.

Csilla Obádovics, $\mathrm{PhD}$, is a professor at the University of Sopron, head of the István Széchenyi Economic and Management Doctoral School, and a senior research fellow in the Hungarian Demographic Research Institute. Her main research interest is population forecasting and its adaptation to a regional and county level, multivariate statistical methods, adapting Human Development Index to the micro-regional level, territorial inequalities.

Balázs Szabó is a researcher and head of department at the Research Institute for National Strategy, and a PhD student at the University of Pécs. His main research area is the social and economic situation of ethnic minorities, regional and rural development.

Dávid Csécsi is a PhD student at Corvinus University of Budapest and a researcher at the Research Institute for National Strategy. His main research interest is geopolitics of Central Europe and the Carpathian region, regional and urban development, homelessness in urban and regional development. 